GRASAS Y ACEITES 70 (3)

July-September 2019, e310

ISSN-L: 0017-3495

https://doi.org/10.3989/gya.0932182

\title{
Nutritional composition and antioxidant activity of different walnut varieties (Juglans regia L.) from Nerpio (Spain) in comparison to commercial varieties
}

\author{
I. Viera-Alcaide ${ }^{\mathrm{a}}$, A. Hamdi, ${ }^{\mathrm{a}, \mathrm{b}}$, A. Jiménez-Araujo ${ }^{\mathrm{a}}$, R. Rodríguez-Arcos ${ }^{\mathrm{a}}$, \\ J.A. Espejo-Calvo ${ }^{c}$ and R. Guillén-Bejarano ${ }^{\mathrm{a},{ }^{2}}$ \\ ${ }^{\text {a }}$ Phytochemicals and Food Quality Group, Instituto de la Grasa (CSIC), Campus of \\ Pablo de Olavide University, Carretera de Utrera Km 1, Building 46, 41013-Sevilla, Spain \\ ${ }^{\text {b}}$ Unité de Physiologie et de Biochimie de la réponse des plantes aux contraintes abiotiques, \\ FST, Campus Universitaire, 2092, Tunis El Manar, Tunisia \\ Innofood I+D Soluciones S.L. \\ ${ }^{凶}$ Corresponding author: rguillen@ig.csic.es
}

Submitted: 11 September 2018; Accepted: 09 November 2018. Published online: 26 April 2019

SUMMARY: In the Nerpio region (Albacete, Spain), endogenous walnut cultivars have been grown since ancient times. None of them has been chemically characterized to valorize them in comparison to commercial varieties. In this work, 47 native $(\mathrm{N})$ and 7 foreign $(\mathrm{F})$ walnut cultivars grown in Nerpio, and 13 commercial (C) samples were studied during three seasons. The average yield, moisture, and protein and oil contents were slightly lower in the $\mathrm{N}$ samples than in $\mathrm{C}$. The composition of fatty acid suggested that the $\mathrm{N}$ walnuts could be more stable against oxidation due to their higher amount of MUFA and lower amount of PUFA. The biological protein value for the samples was similar but the antioxidant capacity marked important differences among them: $\mathrm{N}$ cultivars reached the highest scores, with intermediate $F$ values. Local walnut varieties from Nerpio should be valorized on the basis of their potentially enhanced health benefits, although further studies must be developed on their phytochemicals.

KEYWORDS: Antioxidant activity; Fatty acids; Native varieties; Nerpio; Proteins; Walnut

RESUMEN: Composición nutricional y actividad antioxidante de diferentes variedades de nueces (Juglans regia $L$.) de Nerpio (España) en comparación con variedades comerciales. En Nerpio (Albacete, España) se cultivan tradicionalmente variedades locales de nueces que nunca han sido estudiadas con vistas a su puesta en valor frente a variedades comerciales. En este trabajo se han estudiado 47 variedades locales $(\mathrm{N})$ y 7 extranjeras $(\mathrm{F})$ cultivadas en Nerpio, además de 13 comerciales (C). Los valores medios encontrados para rendimiento, humedad, y contenidos graso y proteico fueron ligeramente inferiores en N. Debido a su composición de ácidos grasos, el aceite de nueces $\mathrm{N}$ podría ser más estable frente a la oxidación. El valor biológico de sus proteínas es muy similar, siendo la actividad antioxidante la que marca una gran diferencia en favor de los cultivares endémicos: las muestras $\mathrm{N}$ dieron los valores más altos, y las $\mathrm{F}$ intermedios. Por ello, las variedades locales de Nerpio podrían tener mayores beneficios para la salud que las variedades comerciales, aunque son necesarios estudios sobre su composición en fitoquímicos.

PALABRAS CLAVE: Ácidos grasos; Actividad antioxidante; Nerpio; Nuez; Proteínas; Variedades autóctonas

ORCID ID: Viera-Alcaide I https://orcid.org/0000-0003-2019-9013, Hamdi A https://orcid.org/0000-0002-6510-8587, Jiménez-Araujo A https://orcid.org/0000-0002-2695-4588, Rodríguez-Arcos R https://orcid.org/0000-0002-0003-4345, Espejo-Calvo JA https://orcid.org/0000-0003-4344-9388, Guillén-Bejarano R https://orcid.org/0000-0001-9034-3012

Citation/Cómo citar este artículo: Viera-Alcaide I, Hamdi A, Jiménez-Araujo A, Rodríguez-Arcos R, Espejo-Calvo JA, Guillén-Bejarano R. 2019. Nutritional composition and antioxidant activity of different walnut varieties (Juglans regia L.) from Nerpio (Spain) in comparison to commercial varieties. Grasas Aceites 70 (3), e310. https://doi.org/10.3989/gya.0932182

Copyright: (C2019 CSIC. This is an open-access article distributed under the terms of the Creative Commons Attribution 4.0 International (CC BY 4.0) License. 


\section{INTRODUCTION}

Walnut consumption has been associated with a lower incidence of cardiovascular disease, diabetes and some types of cancer (Sánchez-González et al., 2017). Since this evidence has been sufficiently justified and documented, walnuts have been included in the dietary recommendations of the United States, Canada and Spain and a health claim has been accepted in relation to their role in the prevention of cardiovascular diseases (EFSA Panel on Dietetic Products, 2011). They have also been postulated as a potential protector of brain health and cognitive function, especially for the elderly population (Poulose et al., 2014).

Nutritionally the walnut has a high fat content, greater than $60 \%$, and its lipid profile is characterized by a high proportion of polyunsaturated fatty acids (PUFA). Proteins represent around 20\% and are especially rich in essential amino acids (USDA, 2018). The main phytochemicals that can be found in its composition are phytosterols, with the most important being sitosterol, avenasterol and campesterol (Amaral et al., 2003; Bada et al., 2010). They also contain significant amounts of two types of antioxidants, phenols and tocopherols (Alasalvar et al., 2015). All these components, together with volatile substances, determine the functional and organoleptic characteristics of walnuts, although in general, these properties depend on the variety, cultivation conditions (Gandev et al., 2014), storage conditions (Christopoulos et al., 2015, ) and post-harvest treatments of the walnuts (Ling et al., 2014).

The production and consumption of walnuts have been increasing steadily in recent years, with worldwide production now at around 4 million tons. In 2016, the main world producers were China (1.78 million tons), the United States (608,000 tons) and Iran (405,000 tons) (FAOSTAT, 2018). Spanish production is quite modest; it is below 16,000 tons (MAPAMA, 2018). In 2015, the total consumption of nuts in Spain was 130,000 tons, with walnuts being the most commonly consumed (30,000 tons), mainly as snacks for household use (MAPAMA, 2017; Martín Cerdeño, 2017). These data, together with the fact that Spain has native varieties with different characteristics from other foreign varieties, cultivars from Asturias (Bada et al., 2010) or Nerpio, suggest that the walnut industry may have good prospects in Spain.

Nowadays, one of the problems presented by the native walnut varieties from Nerpio is that they are basically uncharacterized from a chemical point of view. So, the main objective of this study was to investigate the chemical composition of different varieties of walnuts, with special attention to their antioxidant capacity, in order to determine the possible differences between the native walnut from Nerpio and varieties from France
(Franquette) and the United States (Chandler), which are the most commonly commercialized walnuts in Spain at present.

\section{MATERIALS AND METHODS}

\subsection{Walnut samples}

Samples of approximately $1 \mathrm{~kg}$ were sent by Nerpio growers to the Instituto de la Grasa laboratories. The commercial samples were purchased in different local stores.

The study included a total of 67 samples, from which 54 came from the area of Nerpio and 13 were samples of unknown varieties from different commercial brands (C). From the samples collected in Nerpio, 47 were native varieties (N) and 7 samples (F) were of two foreign varieties cultivated in Nerpio (Franquette from France and Chandler from USA). The samples correspond to three different seasons, 2013-2014, 2015-2016, and 2016-2017 (18, 35, and 14 walnut samples, respectively).

\subsection{Kernel ratio and sphericity}

Twenty fruits were selected randomly from each sample and weighed individually. The kernel of 10 fruits was collected and weighed to calculate the kernel ratio.

The sphericity is the parameter that shows the deviation of the walnut shape from a perfect sphere (Khir et al., 2011). The three different dimensions were measured and the sphericity was calculated as:

Sphericity $=\sqrt[3]{ }($ Width $\times$ Length $\times$ Height $) /$ Length $(1)$

\subsection{Moisture}

Aliquots of kernels $(1 \mathrm{~g} \times 3)$ were dried in an infrared moisture analyzer (Ohaus, MB45) until constant weight. The result is expressed as a $\mathrm{g} / 100 \mathrm{~g}$ fresh weight.

\subsection{Fat content}

The kernel was homogenized with a mortar and pestle. Aliquots of the kernel $(20 \mathrm{~g} \times 3)$ were weighed and extracted by Soxhlet with hexane for 6 hours. After solvent removal by a rotary evaporator, the fat content was determined by gravimetry and expressed as $\mathrm{g}$ fat $/ 100 \mathrm{~g}$ fresh weight.

\subsection{Protein content}

Protein was determined in triplicate by elemental analysis in a Leco Analyzer CHNS-932 (St. Joseph, MI, USA). The 6.25 factor was used to convert the obtained $\% \mathrm{~N}$ into g protein $/ 100 \mathrm{~g}$ fresh weight. 


\subsection{Determination of fatty acid composition by gas chromatography}

The fatty acid composition was determined after methyl ester derivatization (Garcés et al., 1993). $50 \mathrm{mg}$ of homogenized sample were weighed in duplicate. $3.3 \mathrm{~mL}$ of the mixture methanol:toluene: 2,2'-dimethoxypropane:sulfuric acid 117:60:15:6 and $1.7 \mathrm{~mL}$ of $\mathrm{n}$-heptane $95 \%$ and $0.05 \%$ of buthyl-hydroxytoluene were added to each tube. Heptadecanoic acid was added as internal standard. The tubes were placed in a heating block fitted at $85{ }^{\circ} \mathrm{C}$ for two hours. After cooling, the tubes were centrifuged at $200 \mathrm{~g}$. The organic phase $(2 \mathrm{~mL})$ was analyzed by gas chromatography to quantify the methyl esters of fatty acids. A HP 6890 Plus+ gas chromatograph (Hewlett-Packard, Palo Alto, CA, USA) fitted with a $30 \mathrm{~m} \times 250 \mu \mathrm{m} \times 0.20 \mathrm{~mm}$ capillary column (SP-2330, Supelco, Bellefonte, PA, USA) was used. The carrier gas was helium at a constant flow of $1.6 \mathrm{~mL} / \mathrm{min}$. The oven temperature was held isothermally at $165^{\circ} \mathrm{C}$. The injector temperature was $250{ }^{\circ} \mathrm{C}$ and the flame ionization detector was set at $300{ }^{\circ} \mathrm{C}$. The total run time was $24 \mathrm{~min}$. The results were expressed as percent composition of total fatty acids quantified.

\subsection{Determination of amino acid composition by HPLC}

Amino acids were determined by column derivatization with ethoxy methylene malonate (Alaiz et al., 1992). Homogenized kernel samples with $\mathrm{D}$, L-a-aminobutyric acid as internal standard were dissolved in $6.0 \mathrm{M} \mathrm{HCl}$. The solutions were gassed with nitrogen and sealed in hydrolysis tubes under nitrogen, then incubated in an oven at $110^{\circ} \mathrm{C}$ for $24 \mathrm{~h}$. After drying, the samples were dissolved in $1 \mathrm{M}$ sodium borate buffer $(\mathrm{pH} 9.0)(1 \mathrm{~mL})$ containing $0.02 \%$ sodium azide, and $0.8 \mathrm{~mL}$ diethyl ethoxy methylene malonate were added. The reaction was carried out at $50{ }^{\circ} \mathrm{C}$ for $50 \mathrm{~min}$ with vigorous shaking. The resulting mixture was cooled to room temperature and $15 \mathrm{~mL}$ were injected into the chromatograph.

Separation and quantification of the amino acid derivatives were carried out in a Jasco-LCNet II ADC liquid chromatograph system equipped with DAD. Quantification was made by the integration of peak areas at $280 \mathrm{~nm}$, using a binary gradient system. The solvents used were (A) $25 \mathrm{mM}$ sodium acetate containing $0.02 \%$ of sodium azide $(\mathrm{pH} 6.0$ ) and (B) acetonitrile. The flow rate was $0.9 \mathrm{~mL} / \mathrm{min}$ with the following gradient: initially A $91 \%$, B 9\%; linear gradient over 3 min to A $86 \%$, B $14 \%$; held isocratically at A $86 \%$, B $14 \%$ for a further $10 \mathrm{~min}$; linear gradient over $17 \mathrm{~min}$ to B $31 \%$ and held isocratically for $5 \mathrm{~min}$.

For the determination of tryptophan (Yust et al., 2004), samples $(2-10 \mathrm{mg})$ were dissolved in $3 \mathrm{~mL}$ of
$4 \mathrm{~N} \mathrm{NaOH}$, sealed in hydrolysis tubes under nitrogen, and incubated in an oven at $100{ }^{\circ} \mathrm{C}$ for $4 \mathrm{~h}$. The hydrolysates were cooled down on ice, neutralized to $\mathrm{pH} 7$ using $12 \mathrm{~N} \mathrm{HCl}$, and diluted to $25 \mathrm{~mL}$ with $1 \mathrm{M}$ sodium borate buffer ( $\mathrm{pH}$ 9). Standard solutions of tryptophan were prepared as above. The quantification by HPLC was made isocratically with $25 \mathrm{mM}$ sodium acetate, $0.02 \%$ sodium azide (pH 6)/acetonitrile (91:9) at $0.9 \mathrm{~mL} / \mathrm{min}$.

\subsection{Determination of chemical score for amino acids}

The chemical score was calculated from the provisional amino acid scoring pattern (FAO, 2013) as follows:

Amino acid score $=(\mathrm{mg}$ of amino acid in $1 \mathrm{~g}$ test protein $/ \mathrm{mg}$ of amino acid in $1 \mathrm{~g}$ WHO reference standard $\times 100(2)$

To calculate the digestibility-corrected amino acid score (PDCAAS) the amino acid score previously obtained was multiplied by the digestibility of the food protein.

\subsection{Determination of total phenols and antioxidant activity}

For these determinations an ethanolic extract from each sample was taken in duplicate: $2.5 \mathrm{~g}$ of sample were homogenized for $1 \mathrm{~min}$ in an Ultraturrax at top speed with $100 \mathrm{~mL} 80 \%$ ethanol. After centrifugation and filtration, aliquots of the supernatants were analyzed for total phenol and antioxidant activity.

The total phenol content was quantified for each walnut extract according to the Folin-Ciocalteu spectrophotometric method (Singleton et al., 1965), using gallic acid as a reference standard compound. Aliquots of $0.02 \mathrm{~mL}$ of ethanolic extracts were dosified in triplicate, and $0.08 \mathrm{~mL}$ Folin-Ciocalteu phenol reagent $(0.2 \mathrm{M})$ were added to each microplate well and mixed. Then, $0.1 \mathrm{~mL}$ of $\mathrm{Na}_{2} \mathrm{CO}_{3}(75 \mathrm{~g} / \mathrm{L})$ was added and the mixtures were mixed thoroughly and incubated at room temperature for 10 minutes. A microplate reader (550 model from Bio-Rad, Hercules CA, USA) was set at $630 \mathrm{~nm}$. The total phenolic content of the samples was expressed as gallic acid equivalents ( $\mathrm{mg} / \mathrm{g}$ fresh weight).

The antioxidant capacity was studied by two tests: the antiradical capacity against DPPH. expressed as Trolox equivalent antioxidant capacity (TEAC); and the ferric reducing power (FRP) test.

For the determination of TEAC, the method described by Rodríguez et al., (2007) was applied. A microplate reader was used for the absorbance measurements. Briefly, aliquots of $5 \mu \mathrm{L}$ of the ethanolic extract and $195 \mu \mathrm{L}$ of the DPPH. solution $(3.8 \mathrm{mg} / 50 \mathrm{~mL})$ were placed in each microplate well in triplicate. For each sample, a blank with methanol instead of DPPH solution was included. A delay of $30 \mathrm{~min}$ was programmed into the reader to reach 
the steady absorbance. The decrease in absorbance (expressed as percent of the initial absorbance) was plotted against the concentration of the antioxidant solution in the reaction mixture. The efficient concentration EC50 was calculated by regression analysis for each sample and TEAC was expressed as mmol Trolox equivalent $/ \mathrm{kg}$ fresh weight by means of a dose response curve for Trolox.

For FRP, the method was described previously (Rodríguez et al., 2007). $10 \mathrm{~mL}$ of sample and $10 \mu \mathrm{L}$ of $6 \mathrm{mM} \mathrm{FeCl}_{3}$ in $5 \mathrm{mM}$ citric acid were placed in each microplate well in quadruplicate. For each sample, a blank without $\mathrm{FeCl}_{3}$ was included. After dosification, the microplate was incubated for $20 \mathrm{~min}$ at $50^{\circ} \mathrm{C} .180 \mu \mathrm{L}$ of $5 \mathrm{~g} / \mathrm{L}$ dipyridyl solution in $1.2 \%$ trichloroacetic acid were added to each well. A delay of $30 \mathrm{~min}$ was programmed into the reader before reading at $490 \mathrm{~nm}$. FRP was expressed as Trolox equivalents ( $\mathrm{mmol}$ Trolox/ $\mathrm{kg}$ fresh weight).

\subsection{Statistical analysis}

The results are expressed as the average value of at least two repetitions. To assess the differences among samples, a multiple sample comparison (one-way ANOVA) was performed using the Statgraphics ${ }^{\circledR}$ Plus program Version 2.1. The level of significance for the Fisher test was $\mathrm{P}<0.05$. The regression analysis was performed at the same confidence level.

\section{RESULTS AND DISCUSSION}

\subsection{Walnut shape and main nutritional components}

The samples analyzed were from the 2013 and 2015 seasons and the results are presented in Table 1. There were no significant differences in size

TABLE 1. Morphological characteristics and main nutritional components of walnuts (2013-2014 and 2015-2016 seasons) from different varieties.

\begin{tabular}{lrrr}
\hline & N (36) & F (6) & C (11) \\
\hline Size (mm) & $31.24 \pm 3.62 \mathrm{a}$ & $30.73 \pm 1.18 \mathrm{a}$ & $30.49 \pm 1.90 \mathrm{a}$ \\
Weight (g) & $10.98 \pm 3.34 \mathrm{a}$ & $10.90 \pm 1.35 \mathrm{a}$ & $10.92 \pm 2.08 \mathrm{a}$ \\
Yield (\%) & $41.35 \pm 9.07 \mathrm{a}$ & $39.33 \pm 5.40 \mathrm{a}$ & $45.90 \pm 8.14 \mathrm{~b}$ \\
Sphericity & $0.90 \pm 0.05 \mathrm{c}$ & $0.87 \pm 0.05 \mathrm{a}$ & $0.89 \pm 0.04 \mathrm{~b}$ \\
Moisture (\%) & $2.97 \pm 1.05 \mathrm{a}$ & $3.01 \pm 0.69 \mathrm{ab}$ & $3.36 \pm 0.46 \mathrm{~b}$ \\
Fat (\%) & $53.78 \pm 8.25 \mathrm{a}$ & $54.62 \pm 6.79 \mathrm{ab}$ & $56.84 \pm 6.25 \mathrm{~b}$ \\
Protein (\%) & $20.80 \pm 3.89 \mathrm{a}$ & $21.57 \pm 2.02 \mathrm{ab}$ & $23.24 \pm 3.23 \mathrm{~b}$
\end{tabular}

The number in parentheses corresponds to the number of samples analyzed. Each sample has been analyzed at least in triplicate. The results are expressed as mean value \pm standard deviation. The same lower case letters in the rows indicate no significant differences $(\mathrm{P}<0.05)$ among varieties as determined by the one-way ANOVA/Fisher test.

$\mathrm{N}$ : Nerpio native varieties; F: foreign varieties grown in Nerpio; C: commercial samples. or weight; however, the size of the $\mathrm{N}$ samples had a higher standard deviation than the others, suggesting a higher variability among samples. This could be explained by the presence of oversized "Mollar" varieties in the $\mathrm{N}$ group. The diameters of Mollar varieties were in the range of $33.70-45.71 \mathrm{~mm}$, which widened the interval of values for the $\mathrm{N}$ group.

The $\mathrm{C}$ samples had higher yield and higher contents in moisture, fat and protein than $\mathrm{N}$, with $\mathrm{F}$ having intermediate contents. These three samples had a similar composition to the one presented by the USDA (USDA, 2018), but with lower contents in water and fat (4.07 and $65.21 \%$, respectively by USDA) and higher in protein (15.23\%).

Other native walnut varieties were characterized from Asturias (Spain) (Bada et al., 2010). They showed a yield in the same range as the Nerpio varieties $(32-48 \%$, average value $40.36 \%$ ), but higher moisture and fat contents $(4.67-6.77 \%$ and 55.01-67.62\%, with average values of 5.18 and $62.33 \%$, respectively). This increase in moisture could be due to the climatological characteristics of the growing area, since Asturias has higher annual rainfall than Nerpio (Albacete), a mean of 1030 and $378 \mathrm{~mm} /$ year for the period 1975-2017, respectively (Tutiempo.net, 2018). Similar results were found for commercial varieties grown in Portugal (Amaral et al., 2003) and Italy (Ruggeri et al., 1998).

\subsection{Fatty acid composition of walnut oil}

The quantified amounts of fatty acid methylesters are presented in Table 2. For all the samples (2013 and 2015 seasons), linoleic acid (C18:2) was the most abundant (57.21-60.69\%), followed by oleic acid (C18:1, 15.98-20.07\%) and linolenic acid $(\mathrm{C} 18: 3,11.24-13.76 \%)$. The proportions of these fatty acids are considered important for their nutritional value. Minor linoleic acid and linolenic contents result in a longer shelf-life; while higher levels of polyunsaturated fatty acids are more desirable due to their possible health benefits (Ros, 2010).

The $\mathrm{N}$ varieties had significantly higher amounts of palmitic (C16:0) and oleic acids and a smaller amount of linolenic than the $\mathrm{C}$ samples. Oils with high percentages of PUFAs in comparison with saturated ones (SFAs) are very susceptible to oxidation as is the case of walnut oil, which becomes rancid very quickly. This factor (PUFAs/SFAs) also affects the nutritional quality of oil, and a ratio higher than 1.5 is associated with healthy foods (Ribarova et al., 2003). In the case of the $\mathrm{N}$ varieties this factor varied from 6.63-7.10, and 8.00 for C. Other varieties found in the bibliography were in the range 5.94-7.01 for commercial and local varieties grown in Tunisia (Bouabdallah et al., 2014), 7.40-9.93 for native cultivars from Asturias (Spain) (Bada et al., 2010), or 7.03-8.12 for commercial varieties grown in Portugal (Amaral et al., 2003). The $\mathrm{N}$ varieties 
TABLE 2. Fatty acid composition of walnut oil from different varieties (2013-2014 and 2015-2016 seasons) expressed as percent composition.

\begin{tabular}{lccc}
\hline & N (36) & F (6) & C (11) \\
\hline C14:1 & $0.07 \pm 0.07 \mathrm{a}$ & $0.03 \pm 0.05 \mathrm{a}$ & $0.08 \pm 0.08 \mathrm{a}$ \\
C16:0 & $7.72 \pm 0.72 \mathrm{~b}$ & $7.41 \pm 0.50 \mathrm{~b}$ & $6.52 \pm 0.49 \mathrm{a}$ \\
C16:1 & $0.06 \pm 0.07 \mathrm{a}$ & $0.02 \pm 0.04 \mathrm{a}$ & n.d. \\
C18:0 & $2.57 \pm 0.44 \mathrm{a}$ & $2.62 \pm 0.54 \mathrm{a}$ & $2.78 \pm 0.29 \mathrm{a}$ \\
C18:1 & $19.07 \pm 2.64 \mathrm{~b}$ & $20.07 \pm 2.53 \mathrm{~b}$ & $15.98 \pm 2.19 \mathrm{a}$ \\
C18:2 & $59.09 \pm 2.39 \mathrm{~b}$ & $57.21 \pm 2.05 \mathrm{a}$ & $60.69 \pm 2.07 \mathrm{~b}$ \\
C18:3 & $11.24 \pm 1.44 \mathrm{a}$ & $12.50 \pm 1.33 \mathrm{~b}$ & $13.76 \pm 3.19 \mathrm{~b}$ \\
C20:0 & $0.03 \pm 0.06$ & $n . d$. & $n . d$. \\
C20:1 & $0.16 \pm 0.05 \mathrm{ab}$ & $0.14 \pm 0.03 \mathrm{a}$ & $0.19 \pm 0.06 \mathrm{~b}$ \\
SFA & $10.32 \pm 1.22 \mathrm{~b}$ & $10.03 \pm 1.04 \mathrm{ab}$ & $9.30 \pm 0.78 \mathrm{a}$ \\
MUFA & $19.36 \pm 2.83 \mathrm{~b}$ & $20.26 \pm 2.64 \mathrm{~b}$ & $16.25 \pm 2.33 \mathrm{a}$ \\
PUFA & $70.39 \pm 2.97 \mathrm{a}$ & $69.73 \pm 3.18 \mathrm{a}$ & $74.58 \pm 2.79 \mathrm{~b}$ \\
\hline
\end{tabular}

The number in parentheses corresponds to the number of samples analyzed. Each sample has been analyzed at least in duplicate. The results are expressed as mean value \pm standard deviation. The same lower case letters in the rows indicate no significant differences $(\mathrm{P}<0.05)$ among varieties as determined by the one-way ANOVA/Fisher test.

$\mathrm{N}$ : Nerpio native varieties; $\mathrm{F}$ : foreign varieties grown in Nerpio; $\mathrm{C}$ : commercial samples; n.d.: not detected; SFA: saturated fatty acids; MUFA: monounsaturated fatty acids; PUFA: polyunsaturated fatty acids.

had the most favorable ratio for stability against oxidation, together with those from Tunisia, suggesting an influence of geographical and/or climatological characteristics of the cultivation zone, apart from variety. The $\mathrm{N}$ values (6.6-7.1) suggested higher stability against oxidation, high enough to ensure their beneficial effects on health. In our study, the amounts of monounsaturated fatty acids (MUFA) for samples $\mathrm{N}$ and $\mathrm{F}$ were much higher than for $\mathrm{C}$, decreasing in the same percentage of PUFA. MUFAs have a great advantage over PUFA in that the enrichment of lipoprotein lipids with MUFA increases their resistance to oxidation. The $\mathrm{N}$ and $F$ varieties are more stable against oxidation and therefore present greater benefits against oxidative stress (López-Uriarte et al., 2018). Another factor which is studied as an index for stability is the ratio of oleic/linoleic acid (Aparicio et al., 1999). $\mathrm{N}$ had an average value for this index of $0.34, \mathrm{~F} 0.32$, and $\mathrm{C} 0.26$. The $\mathrm{N}$ and $\mathrm{F}$ factors were much higher than those found for Asturias (0.25), Portugal (0.29), and Tunisia (0.25) varieties (Amaral et al., 2003; Bada et al., 2010; Bouabdallah et al., 2014), suggesting a higher oil stability.

The fatty acid composition is also interesting from a nutritional point of view, besides its relevance in rancidity prevention. PUFAs have been shown to boost brain health even in elderly people. The human metabolism synthesizes EPA (eicosapentaenoic acid, C20:5(n-3)) and DHA (docosahexaenoic acid, C22:6(n-3)) from linolenic acid, which reduce oxidative stress, enhance immune function, and maintain synaptic plasticity, neuronal membrane stability, gene expression, and neurogenesis (Poulose et al., 2014). Thus, including walnuts in the human diet could delay neurodegenerative diseases and age-related cognitive decline.

In addition, as part of a mixed diet in healthy adults, walnuts provide less energy available (21\%) than predicted by the Atwater factors (Novotny et al., 2012), which may help explain why nut consumers do not gain excess weight. In fact, the ingestion of walnuts can help in the control of satiety and in the increase of thermogenesis (Baer et al., 2015).

The different results for the fatty acid profile obtained indicate that there are differences among the varieties of $\mathrm{N}, \mathrm{F}$ (cultivated in Nerpio) and $\mathrm{C}$ walnuts, and that these results can be significant for selection studies in order to better identify the different varieties of walnuts for diets. Variations in fatty acid composition can affect the final use of the product, so it would be useful to select cultivars for particular uses; for example, the use of varieties to obtain a healthy end product which is rich in polyunsaturated fatty acids or, others which have high levels of oleic, linoleic and linolenic acids should be preferable if the walnuts were destined to be used in a diet to reduce cholesterol.

\subsection{Walnut proteins and amino acids}

The amino acid composition of walnut proteins is presented in Table 3 (2015 season). Glutamic acid (Glu), arginine (Arg) and aspartic acid (Asp) were the most abundant in all the samples, accounting for nearly $50 \%$ of the total amino acids. Only isoleucine (Ile) and tryptophan (Trp) showed significant differences among varieties. The $\mathrm{F}$ samples were poorer in both amino acids than $\mathrm{C}$ samples, and only in Ile for $\mathrm{N}$ samples.

It is necessary to calculate the chemical score for essential amino acids in order to evaluate the protein quality. The three samples analyzed showed few differences, and were rich in histidine (His), threonine (Thr), leucine (Leu), phenylalanine (Phe) and tyrosine (Tyr), with scores higher than $100 \%$ (data not shown). The amino acid Trp is of special interest because it is the precursor in the biosynthesis pathway to melatonin and serotonin, hormones of great interest for controlling circadian cycles, for inducing a feeling of wellness and for their benefits to the cardiovascular system. In rats, just four hours after walnut ingestion, melatonin increased in blood plasma and its antioxidant capacity increased (Reiter et al., 2005). The Trp score was higher than $50 \%$ for $\mathrm{N}$ and $\mathrm{C}$ samples, so they can be considered as an important source of this essential amino acid. The limiting amino acid was valine (Val) in all 
TABLE 3. Amino acid composition of walnut protein from different varieties (2015-2016 season) expressed as percent composition.

\begin{tabular}{lccc}
\hline & $\mathbf{N}(\mathbf{2 1})$ & $\mathbf{F ~ ( 5 )}$ & $\mathbf{C}(\mathbf{9})$ \\
\hline Aspartic acid & $11.83 \pm 0.70 \mathrm{a}$ & $12.15 \pm 0.71 \mathrm{a}$ & $11.77 \pm 1.04 \mathrm{a}$ \\
Glutamic acid & $20.62 \pm 1.22 \mathrm{a}$ & $21.11 \pm 1.37 \mathrm{a}$ & $20.49 \pm 1.83 \mathrm{a}$ \\
Serine & $7.07 \pm 0.49 \mathrm{a}$ & $7.37 \pm 0.50 \mathrm{a}$ & $7.00 \pm 0.68 \mathrm{a}$ \\
Histidine & $2.57 \pm 0.42 \mathrm{a}$ & $2.41 \pm 0.34 \mathrm{a}$ & $2.60 \pm 0.47 \mathrm{a}$ \\
Glycine & $6.68 \pm 0.30 \mathrm{ab}$ & $6.90 \pm 0.45 \mathrm{~b}$ & $6.49 \pm 0.53 \mathrm{a}$ \\
Threonine & $3.27 \pm 0.26 \mathrm{a}$ & $3.23 \pm 0.20 \mathrm{a}$ & $3.17 \pm 0.38 \mathrm{a}$ \\
Arginine & $13.36 \pm 0.78 \mathrm{a}$ & $13.28 \pm 0.48 \mathrm{a}$ & $13.41 \pm 1.42 \mathrm{a}$ \\
Alanine & $4.85 \pm 1.14 \mathrm{a}$ & $5.11 \pm 0.59 \mathrm{a}$ & $5.00 \pm 0.56 \mathrm{a}$ \\
Proline & $2.56 \pm 1.37 \mathrm{a}$ & $3.12 \pm 1.03 \mathrm{a}$ & $2.51 \pm 1.23 \mathrm{a}$ \\
Tyrosine & $3.01 \pm 0.20 \mathrm{a}$ & $2.96 \pm 0.20 \mathrm{a}$ & $2.95 \pm 0.31 \mathrm{a}$ \\
Valine & $1.97 \pm 0.71 \mathrm{a}$ & $1.87 \pm 0.72 \mathrm{a}$ & $2.13 \pm .60 \mathrm{a}$ \\
Methionine & $0.78 \pm 0.29 \mathrm{a}$ & $0.77 \pm 0.45 \mathrm{a}$ & $0.62 \pm 0.25 \mathrm{a}$ \\
Cysteine & $1.44 \pm 0.51 \mathrm{a}$ & $1.37 \pm 0.63 \mathrm{a}$ & $1.70 \pm 0.27 \mathrm{a}$ \\
Isoleucine & $2.05 \pm 0.23 \mathrm{a}$ & $1.87 \pm 0.21 \mathrm{a}$ & $2.23 \pm 0.31 \mathrm{~b}$ \\
Tryptophan & $0.45 \pm 0.09 \mathrm{ab}$ & $0.41 \pm 0.04 \mathrm{a}$ & $0.49 \pm 0.13 \mathrm{a}$ \\
Leucine & $7.39 \pm 0.44 \mathrm{a}$ & $7.53 \pm 0.51 \mathrm{a}$ & $7.29 \pm 0.79 \mathrm{a}$ \\
Phenylalanine & $5.33 \pm 0.62 \mathrm{a}$ & $5.35 \pm 0.41 \mathrm{a}$ & $5.51 \pm 0.75 \mathrm{a}$ \\
Lysine & $3.14 \pm 0.39 \mathrm{a}$ & $2.95 \pm 0.19 \mathrm{a}$ & $3.22 \pm 0.81 \mathrm{a}$ \\
\hline
\end{tabular}

The number in parentheses corresponds to the number of samples analyzed. Each sample has been analyzed at least in duplicate. The results are expressed as mean value \pm standard deviation. The same lower case letters in the row indicate no significant differences $(\mathrm{P}<0.05)$ among varieties as determined by the onewayANOVA/Fisher test.

$\mathrm{N}$ : Nerpio native varieties; $\mathrm{F}$ : foreign varieties grown in Nerpio; $\mathrm{C}$ : commercial samples.

cases. These scores have been calculated based on 2013 FAO/WHO recommendations (FAO, 2013). The average scores for walnut protein were 89.61, 86.60 and 90.84 for N, F and C samples, respectively. The FAO/WHO defined the protein PDCAAS as the preferred method for a routine prediction of the protein quality of food products for human nutrition. Nut and almond protein digestibility is $73.03 \%$ (Suárez López et al., 2006), so the PDCAAS for our samples were 65.44, 63.24 and 66.34 for $\mathrm{N}, \mathrm{F}$ and $\mathrm{C}$, respectively, suggesting a very similar protein quality for Nerpio cultivars and commercial walnuts. These values were similar to those found for fruits and some cereals (Suárez López et al., 2006).

\subsection{Total phenol contents and antioxidant capacity}

Total phenols have been quantified by the FolinCiocalteu method and the antioxidant capacity by two different assays (TEAC and FRP). The results for the three seasons are presented in Table 4 . N samples had the highest content in total phenols, which led to the highest antioxidant capacity in both assayed methods. Indeed, the Folin method should
TABLE 4. Total phenol contents by the Folin method (mg/g fresh weight), antiradical activity (TEAC) ( $\mathrm{mmol}$ Trolox equivalent $/ \mathrm{kg}$ fresh weight) and ferric reducing power (FRP) (mmol Trolox equivalent/kg fresh weight) of walnuts from the different varieties (2013-2014. 2015-2016 and 2016-2017 seasons)

\begin{tabular}{lccc}
\hline & $\mathbf{N}(\mathbf{4 7 )}$ & $\mathbf{F ~ ( 7 )}$ & $\mathbf{C ~ ( 1 3 )}$ \\
\hline Folin & $10.00 \pm 3.15 \mathrm{~b}$ & $8.61 \pm 2.04 \mathrm{a}$ & $8.05 \pm 2.88 \mathrm{a}$ \\
TEAC & $177.35 \pm 34.50 \mathrm{c}$ & $143.89 \pm 35.02 \mathrm{~b}$ & $98.73 \pm 40.75 \mathrm{a}$ \\
FRP & $186.39 \pm 54.62 \mathrm{~b}$ & $175.67 \pm 53.16 \mathrm{~b}$ & $119.04 \pm 33.78 \mathrm{a}$ \\
\hline
\end{tabular}

The number in parentheses corresponds to the number of samples analyzed. Each sample has been analyzed at least with six replicates. The results are expressed as mean value \pm standard deviation. The same lower case letters in the rows indicate no significant differences $(\mathrm{P}<0.05)$ among varieties as determined by the one-way ANOVA/Fisher test.

$\mathrm{N}$ : Nerpio native varieties; F: foreign varieties grown in Nerpio; C: commercial samples; TEAC: Trolox equivalent antioxidant capacity; FRP: ferric reducing power.

be better considered as another assay for antioxidant activity, especially in samples with a complex composition in antioxidants, as is the case of walnuts. The $\mathrm{C}$ group had the lowest level quantified. The activity quantified for $\mathrm{N}$ was similar to that described for blueberries, F for Granny Smith apples and $\mathrm{C}$ for carrots $(191,143$, and $102 \mathrm{mmol}$ Trolox/ $\mathrm{kg}$, respectively) (Lutz et al., 2015). The fact that $\mathrm{F}$ samples had intermediate values points to the idea that, apart from varietal factors, the growing zone also influenced walnut composition. It is important to note that the three groups of samples were clearly differentiated on the basis of their antioxidant activity, whatever the method used, as shown by the average value of the three seasons (Table 4) and confirmed by the ANOVA study ( 67 samples $\times$ 6 replicates each $=402$ observations).

Among nuts, walnuts had the highest antioxidant activity (120 mmol Trolox $/ \mathrm{kg}$ ), followed by pecans (58 mmol Trolox $/ \mathrm{kg}$ ), peanuts and chestnuts (both around $6 \mathrm{mmol}$ Trolox/kg) (Abe et al., 2010). In the American diet in 2008, the antioxidants from nuts comprised around $19 \%$ of the daily intake, with vegetables, fruits and grains accounting for $25 \%$ each; in Spain it was about $12 \%$, with an increased percentage due to olive oil consumption (Vinson et al., 2012). Consuming walnuts with high antioxidant content, such as the Nerpio ones, would enhance the polyphenol intake and reduce caloric intake.

In Figure 1, the results of the regression analysis between antioxidant activity (TEAC and FRAP) and total phenol content of the 67 samples analyzed during three seasons is presented. Both $\mathrm{R}^{2}$ values indicated that there is no correlation $(0.1795$ and 0.2142 for TEAC and FRAP, respectively) between them and total phenol content. The antioxidants from walnuts are a very complex group of phytochemicals with different structures: phenols (proanthocyanidins, hydrolysable tannins, phytate, 


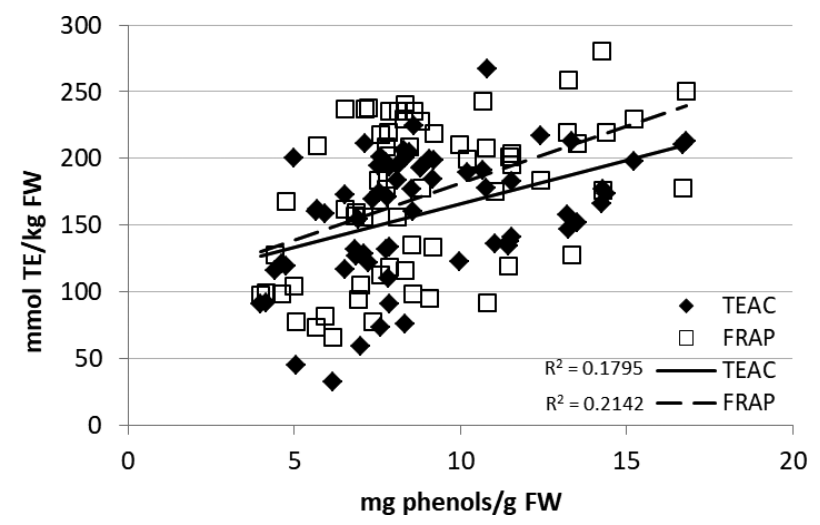

FIGURE 1. Regression analysis of total phenol content (mg/g fresh weight) against antioxidant activity ( $\mathrm{mmol}$ Trolox equivalent $/ \mathrm{kg}$ fresh weight). Each point is the mean value of six determinations. TEAC: antiradical capacity; FRAP: ferric reducing antioxidant power.

flavonoids, phenolic acids, stilbenes), tocopherols, phytosterols, melatonin and selenium (Alasalvar et al., 2015); and it is complicated to relate such an intricate composition to a simple colorimetric assay, which should be better considered as another assay for antioxidant capacity. It is important to note that most of the walnut's antioxidant activity is related to its content in hydrolysable tannins (Arranz et al., 2008), which cannot be extracted with aqueousorganic solvents. Thus, the real antioxidant capacity of the studied samples could be higher than reported. Further studies on the identification and quantification of different antioxidant phytochemicals in walnuts must be developed.

\section{CONCLUSIONS}

Endemic walnut varieties from Nerpio (Albacete, Spain) have distinctive characteristics when compared to the commercial ones. Although they have slightly lower yield and content of main nutritional components (fat and proteins), the composition of the fatty acids, with a higher percentage of MUFA and a lower percentage of PUFA, makes their oil more stable against oxidation than commercial varieties, while maintaining their healthy properties. However, the only parameter which classifies the samples according to their origin is the antioxidant activity. The three methods used, Folin, TEAC and FRAP agree in clearly distinguishing the commercial samples from those from the Nerpio area. It is important to note that the Nerpio region is interesting not only for its own walnut varieties, but also as a walnut growing area because $\mathrm{F}$ varieties (Franquette from France and Chandler from the United States) had intermediate values between $\mathrm{N}$ and $\mathrm{C}$ samples, suggesting an influence of geographical and climatological characteristics of Nerpio on the chemical composition of walnuts. Further studies on antioxidant phytochemicals must be carried out in order to identify the responsible compounds for this improved characteristic.

\section{ACKNOWLEDGEMENT}

This work has been supported by the "Asociación de Productores de Nuez de Nerpio" by a research contract n 20163938 .

\section{REFERENCES}

Abe LT, Lajolo FM, Genovese MI. 2010. Comparison of phenol content and antioxidant capacity of nuts. Ciencia Tecnol. Alim. 30 (1), 254-259. https://doi.org/10.1590/ S0101-20612010000500038

Alaiz M, Navarro JL, Girón J, Vioque E. 1992. Amino acid analysis by high-performance liquid chromatography after derivatization with diethyl ethoxymethylenemalonate. J. Chromatogr. 591, 181-186. https://doi.org/10.1016/ 0021-9673(92)80236-N

Alasalvar C, Bolling BW. 2015. Review of nut phytochemicals, fat-soluble bioactives, antioxidant components and health effects. Brit. J. Nutr. 113, S68-S78. https://doi.org/10.1017/ S0007114514003729

Amaral JS, Casal S, Pereira JA, Seabra RM, Oliveira BP. 2003. Determination of sterol and fatty acid composition, oxidative stability, and nutritioal value of six walnut (Juglans regia L.) cultivars grown in Portugal. J. Agric. Food Chem. 51, 7698-7702. https://doi.org/10.1021/jf 030451d

Aparicio R, Roda L, Albi MA, Gutiérrez F. 1999. Effect of various compounds on virgin olive oil stability measured by rancimat. J. Agric. Food Chem. 47, 4150-4155. https://doi. org/10.1021/jf9812230

Arranz S, Pérez-Jiménez J, Saura-Calixto F. 2008. Antioxidant capacity of walnut (Juglans regia L.): contribution of oil and defatted matter. Eur. Food Res. Technol. 227, 425-431. https://doi.org/10.1007/s00217-007-0737-2

Bada JC, León-Camacho M, Prieto M, Copovi P, Alonso L. 2010. Characterization of walnut oils (Juglans regia L.) from Asturias, Spain. J. Am. Oil Chem. Soc. 87, 1469-1474. https://doi.org/10.1007/s11746-010-1629-3

Baer DJ, Gebauer SK, Novotny JA. 2015. Walnuts consumed by healthy adults provide less available energy than predicted by the Atwater factors. J. Nutr. 146, 9-13. https:// doi.org/10.3945/jn.115.217372

Bouabdallah I, Bouali I, Martínez-Force E, Albouchi A, Pérez Camino MC, Boukhchina S. 2014. Composition of fatty acids, triacylglycerols and polar compounds of different walnut varieties (Juglans regia L.) from Tunisia. Nat. Prod. Res. 28, 1826-1833. https://doi.org/10.1080/14786419. 2014.950573

Christopoulos MV, Tsantili E. 2015. Oil composition in stored walnut cultivars-quality and nutritional value. Eur. J. Lipid Sci. Technol. 117, 338-348. https://doi.org/10.1002/ ejlt.201400082

EFSA Panel on Dietetic Products NaAN. 2011. Scientific opinion on the substantiation of health claims related to walnuts and mainenance of normal blood LDL-cholesterol concentrations (ID 1156,1158) and improvement of endotelium-dependent vasodilatation (ID 1155,1157 ) pursuant to Article 13(1) of regulation (EC) No 1924/2006. EFSA J. 9, 2074. https://doi.org/10.2903/j.efsa.2011.2074

FAO. 2013. Dietary Protein Quality Evaluation in Human Nutrition. FAO, Rome.

FAOSTAT. 2018. http://www.fao.org/faostat/en/\#data/QC/. Last accesed 13/06/2018

Gandev S, Dzhuvinov V. 2014. Evaluation of some walnut cultivars under the climatic conditions of South Bulgaria. Agro-Knowledge J. 15, 5-16. 
Garcés R, Mancha M. 1993. One-step lipid extraction and fatty acid methyl esters preparation from fresh plant tissues. Anal. Biochem. 211, 139-143. https://doi.org/10.1006/ abio.1993.1244

Khir R, Pan Z, Atungulu GG, Thompson JF, Shao D. 2011. Size and moisture distribution characteristics of walnuts and their components. Food Bioprocess Technol. https:// doi.org/10.1007/s11947-011-0717-1

López-Uriarte P, Bulló M, Casas-Agustench P, Babio N, Salas-Salvadó J. 2018. Nuts and oxidation: a systematic review. Nutr. Rev. 67, 497-508. https://doi.org/10.1111/ j.1753-4887.2009.00223.x

Ling B, Hou L, Li R, Wang S. 2014. Thermal treatment and storage condition effects on walnut paste quality associated with enzyme inactivation. Food Sci. Technol. 59, 786793. https://doi.org/10.1016/j.lwt.2014.07.005

Lutz M, Hernández J, Henríquez C. 2015. Phenolic content and antioxidant capacity in fresh and dried fruits and vegetables grown in Chile. CyTA - J. Food 13, 541-547.

MAPAMA. 2017. Informe del consumo de alimentación en España 2016. (ed. AyMA Ministerio de Agricultura y Pesca), p. 242. MAPAMA, Madrid.

MAPAMA. 2018. https://www.mapama.gob.es/es/estadistica/ temas/estadisticas-agrarias/agricultura/superficies-producciones-anuales-cultivos/ Last accesed 13/06/2018.

Martín Cerdeño VJ. 2017. Consumo de frutos secos en España. Distribución Consumo 103, 1-8.

Novotny JA, Gebauer SK, Baer DJ. 2012. Discrepancy between the Atwater factor predicted and empirically measured energy values of almonds in human diets. Am. J. Clin. Nutr. 96, 296-301. https://doi.org/10.3945/ajcn.112.035782

Poulose SM, Miller MG, Shukitt-Hale B. 2014. Role of walnuts in maintaining brain health with age. J. Nutr. 144, 561-566S. https://doi.org/10.3945/jn.113.184838

Reiter RJ, Manchester LC, Tan D. 2005. Melatonin in walnuts: Influence of levels of melatonin and total antioxidant capacity of blood. Nutrition 21, 920-924. https://doi. org/10.1016/j.nut.2005.02.005
Ribarova F, Zanev R, Shishkov S, Rigov N. 2003. $\alpha$-Tocoferol, fatty acids and their correlations in Bulgarian foodstuffs. $J$ Food Compos. Anal. 16, 659-667. https://doi.org/10.1016/ S0889-1575(03)00079-6

Rodríguez G, Rodríguez R, Fernández-Bolaños J, Guillén R, Jiménez A. 2007. Antioxidant activity of effluents during the purification of hydroxytyrosol and 3,4-dihydroxyphenyl glycol from olive oil waste. Eur. Food Res. Technol. 224, 733-741. https://doi.org/10.1007/s00217-006-0366-1

Ros E. 2010. Health benefits of nut consumption. Nutrients 2, 652-682. https://doi.org/10.3390/nu2070652

Ruggeri S, Cappelloni L, Carnovale E. 1998. Chemical composition and nutritive value of nuts grown in Italy. Ital. J. Food Sci. 3, 243-252

Sánchez-González C, Ciudad CJ, Noé V, Izquierdo-Pulido M. 2017. Health benefits of walnut polyphenols: an exploration beyond their lipid profile. Crit. Rev. Food Sci. Nutr. 57, 3373-3383. https://doi.org/10.1080/10408398.2015.1126218

Singleton VL, Rossi JAJ. 1965. Colorimetry of total phenolics with phosphomolibdic-phosphotungstic acid reagents. Am. J. Enol. Viticult. 16, 144-158.

Suárez López MM, Kinlansky A, López LB. 2006. Evaluación de la calidad de la proteína de los alimentos calculando el escore de aminoácidos corregido por digestibilidad. Nutr. Hosp. 21, 47-51.

Tutiempo.net. 2018. https://www.tutiempo.net/clima/espana. html. Last accesed 29/10/2018.

USDA. 2018. USDA Branded Food Products Database. https:// ndb.nal.usda.gov/ndb/foods. Last accesed 13/06/2018.

Vinson JA, Cai Y. 2012. Nuts, especially walnuts, have both antioxidant quantity and efficacy and exhibit significant potential health benefits. Food Funct. 3, 134-140. https:// doi.org/10.1039/c2fo10152a

Yust MM, Pedroche J, Girón-Calle J, Vioque J, Millán F, Alaiz M. 2004. Determination of tryptophan by highperformance liquid chromatography of alkaline hydrolysates with spectrophotometric detection. Food Chem. 85, 317-320. https://doi.org/10.1016/j.foodchem.2003.07.026 